\title{
Critical thinking skill development: Analysis of a new learning management model for Thai high schools
}

\section{Ken Changwong}

King Mongkut's Institute of Technology Ladkrabang (KMITL),

Bangkok, Thailand

ken.changwong@gmail.com

\section{Aukkapong Sukkamart}

King Mongkut's Institute of Technology Ladkrabang (KMITL),

Bangkok, Thailand

auk2519@gmail.com

\section{Boonchan Sisan}

King Mongkeut's Institute of Technology Ladkrabang (KMITL), Bangkok, Thailand

kiboonch@kmitl.ac.th

Abstract. Under the vision outlined in Thailand 4.0, critical thinking skills have become one of the key pillars of a new, knowledge-based economy. However, the 2015 Thailand Research Fund study that evaluated the logical thinking and analytical skills of 6,235 students in ten provinces of Thailand, found that the average score was $36.5 \%$, with only $2.09 \%$ of all students passing. Recognizing the severity of the crisis, nine experts met in August 2017 as a focus group and were tasked by the researchers to help with the development of a new critical thinking learning management model. From this, a five-step learning management model was conceptualized, which the authors called the PUSCU Model'. By means of cluster random sampling, 69 students were selected, from which two sub-groups were formed. One group of 35 experimental studies students, and one group consisting of 34 traditional learning students. The PUSCU model was tested for 16 weeks, from November 2016 through February 2017. The Statistical Package for the Social Sciences (SPSS) 21 software was used to conduct a one-way Multivariate Analysis Of Variance (MANOVA) to determine whether there were any differences between the control and the experimental groups. The results indicated that the experimental group had higher average scores in terms of critical thinking ability and academic achievement, and its members were satisfied with a high level of the model performance, particularly, with the instructor's use of the developed learning materials. 
Keywords: critical thinking, high-school students, learning management, secondary education, PUCSC model, Thailand 4.0.

JEL Classification: I20, I21, I23, I25

\section{INTRODUCTION}

Preparing students to be able to think critically is one of the key goals for many professionals in higher education, and it is also a quality sought by most employers of university graduates (Sulaiman, Rahman, \& Dzulkifli, 2008). Under a Thailand 4.0 vision, critical thinking skills are stated to be a key pillar among the goals for a new, knowledge-based economy (Jones \& Pimdee, 2017). These skills, however, are limited, as according to a recent study evaluating logical thinking and analytical skills, of 6,235 students in ten Thai provinces, the average final score was just 36.5\%, with only 2.09\% passing the exam (Rujivanarom, 2016).

Over 2,500 years ago Plato in his discussions of logic indicated that critical thinking is the tool that helps individuals find answers or solutions to a person's confusions and problems (Thayer-Bacon, 1998). Socrates, Plato's teacher, believed that discussion and critical thinking with knowledge reside in the mind of the individual, rather than a teacher transmitting knowledge to a student (Ornstein \& Levine, 2006). Nearly 2,500 years later, scholars and educators are still discussing the mechanisms, importance, and outcomes of critical thinking skills (or lack thereof).

Contemporary evidence of the importance of critical thinking skills for employment has been provided from the National Association of Colleges and Employers [NACE] (2016) which indicated that critical thinking/problem-solving skills were ranked most important by the 144 surveyed employers (Table 1). This is also consistent with the research results obtained by Bassham, Irwin, Nardone, and Wallace (2013) which indicated that college education is responsible for the development of critical thinking skills which, in their turn, lead to higher-order thinking. This is also consistent with (Costa \& Kallick, 2014) who stated that critical thinking skills are consistently included in all the lists of essentials behind college and career readiness (Kraisuth \& Panjakajornsak, 2017).

Table 1

How Employers Rate Career Readiness Competencies in Terms of Their Essential Need

\begin{tabular}{|l|c|}
\multicolumn{1}{|c|}{ Competency } & Essential Need Rating 2016 \\
\hline Critical Thinking/Problem Solving & 4.7 \\
\hline Professionalism/Work Ethics & 4.7 \\
\hline Teamwork/Collaboration & 4.6 \\
\hline Oral/Written Communication & 4.4 \\
\hline Information Technology Application & 3.9 \\
\hline Leadership & 3.9 \\
\hline Career Management & 3.6 \\
\hline
\end{tabular}

Note. Weighted average. Rated on the 5 -point scale where $1=$ Not essential; $2=$ Not very essential; 3 = Somewhat essential; 4 = Essential; 5 = Absolutely essential.

Source. Job Outlook 2016 Spring Update (National Association of Colleges and Employers, 2016).

Many scholars and studies have also discussed the importance of critical thinking skills in the context of 21st Century education and workforces (Geertsen, 2003). Barrington, Casner-Lotto, and Wright (2006), 
also discussed critical thinking education in the context of students' abilities to enter a modern, $21^{\text {st }}$ century workforce. Reeve (2016) also pointed out the importance of $21^{\text {st }}$ century and critical thinking skills needed by Thai students for their technical and vocational education and training (TVET). This is consistent with Chaiyasut, Samuttai, Phuwiphadawa, and Inthanet (2014), who indicated that critical thinking is one of the 13 life-long learning indicators. The Organisation for Economic Co-operation and Development (OECD) and the United Nations Educational, Scientific and Cultural Organization (UNESCO) (OEC/UNESCO, 2016) reviewed Thai education policy and concluded that information and communication technologies (ICT) should be used in problem-solving and critical thinking more. Directives of the European Union (2015) also mention the urgent need for high-quality knowledge, skills, and competences developed through life-long learning, which focuses on learning outcomes for employability, innovation, active citizenship, and well-being.

Siemens (2005) discussed connectivism and its meaning in the digital age and the half-life of knowledge, which was defined as the time span from when knowledge is gained to when it becomes obsolete, with the amount of knowledge doubling every 18 months. Connectivism is therefore driven by the understanding that decisions are based on rapidly altering foundations. New information is continually being acquired. The ability to draw distinctions between important and unimportant information is vital (critical thinking). The ability to recognize when new information alters the landscape based on the decisions made yesterday, is also critical.

Costa and Kallick (2014) researched what is critical thinking and what is blocking its widespread teaching, transferring, and assessing in the 21 st Century Classrooms? The answer from their research indicated that critical thinking is a mental process. From this, individuals need to actively and skillfully conceptualize, apply, analyze, synthesize, and evaluate information to reach an answer or conclusion.

From the above overview on the importance of critical thinking skills, the researchers sought out to conceptualize a learning management model of the factors important for the enhancement of critical thinking skills of Thai high school students.

\subsection{Statement of the problem}

The recognition of the importance of critical thinking abilities dates back over 2,500 years to Plato, with numerous scholars having discussed the importance of critical thinking in education (Dewey, 1910; Galinsky, 2010; Paul \& Elder, 2008, 2014a, 2014b; Paul, Elder, \& Bartell, 1997; Sternberg, 1997). Added to this volume of work, many contemporary studies have discussed the importance of critical thinking in a 21 st Century workforce and in a knowledge-based economy (European Union, 2015; Jones \& Pimdee, 2017; National Association of Colleges and Employers [NACE], 2016; OECD/UNESCO, 2016; Reeve, 2016). Under the Thailand 4.0 initiative, critical thinking and innovation are key pillars for future growth, prosperity, and a better quality of life. Therefore, the researchers undertook a study to develop a new learning management model to help guide educators in the development and evaluating of Thai high school student critical thinking skills.

\section{LITERATURE REVIEW}

The ability to think critically has been identified as an essential life skill (Galinsky, 2010), with current literature revealing that explicit instruction in, and practice of, critical thinking strategies in the high school classroom can improve student academic performance (Hove, 2011). UNICEF, UNESCO and WHO list problem solving and critical thinking as two of ten core life skill strategies and techniques (UNODC, n/d; World Health Organization, 1999). 
For philosophical teachers, the role model is Socrates, for whom education was nothing less than an examination of life itself (Paul et al., 1997). Over 2,500 years ago, Socrates taught in a non-dogmatic fashion, subjecting the ideas of his students to rigorous, critical questioning (Taylor, 2012). The goal of this process was two-fold: to show them that they didn't know what they thought they did and to push them into critically examining their ideas for themselves. Boa, Wattanatorn, and Tagong (2018) adopted the Socratic Method for Thai undergraduate students, and indicated there were three critical thinking competencies. These included recognize assumptions, evaluate arguments, and draw conclusions. Furthermore, Paul and Elder (2008), stated that the Socratic method has been demonstrated for ages as the most powerful teaching method for enhancing critical thinking skills. It is clear that critical thinking is really important for classroom, workplace, and especially for daily life (Ornstein, Pajak, \& Ornstein, 2011), but teaching and evaluation of critical thinking in the current collegiate environment and curricula are insufficient (Gupta, 2005).

Paul et al. (1997) also noted that teacher preparation was crucial in the teaching of critical thinking. Hager and Kaye (2006) also stated that being an effective critical thinker makes a major contribution to being an effective teacher. In the Cornell Critical Thinking Test Level X, four crucial abilities are tested. The teacher thinking research suggests that there are four abilities central to effective teaching. These include: (1) inductive thinking; (2) judging credibility of observation reports; (3) deductive thinking; and (4) assumption identification.

Each year the National Council for Excellence in Critical Thinking (NCECT) (2017) meets to discuss critical thinking. NCECT states that critical thinking is defined by an intellectually disciplined process of actively and skillfully conceptualizing, applying, analyzing, synthesizing, and/or evaluating information gathered from, or generated by, observation, experience, reflection, reasoning, or communication, as a guide to belief and action.

Today, adoption of critical thinking strategies can also prepare students for the rigors of university life, as well as helping them develop the skills necessary to compete economically in a global environment (Taylor, 2012). Furthermore, Paul and Elder (2014a) noted that critical thinkers must be, "clear as to the purpose at hand and the question at issue...question information, conclusions, and points, of view ...strive to be clear, accurate, precise, and relevant...seek to think beneath the surface, to be logical and fair...[and] apply these skills to their reading and writing as well as to their speaking and listening." However, Mendelman (2007) warned, that today, more and more children grow up engaged with passive activities like $\mathrm{TV}$, video games, and the internet. Therefore, teaching critical thinking is one of the most important, if not the most difficult burdens of the classroom.

According to Innis (2015), critical thinking involves several steps, most of which adults breeze though without much thought. These steps include identify the issue, think about the goal, brainstorm possible solutions, think through possible results, try one of the solutions, and finally, evaluate the outcome. However, Hayes and Devitt (2008) indicated that in early learners, critical thinking strategies are not extensively developed or practiced during primary and secondary education. Teachers are therefore, obligated to help students develop the skills necessary to synthesize the nuances of a modern, complex society.

As students progress into junior and senior high school, critical thinking skills, decision-making skills, and information gathering skills need to be taught. The individual must also be skilled at evaluating the future consequences of their present actions and the actions of others. They need to be able to determine alternative solutions and to analyze the influence of their own values and the values of those around them (Hove, 2011). Rather than accepting information at face value, educated critical thinkers can thoughtfully explore the broader perspectives of an issue. The National Association for Media Literacy Education (2010) advocated explicit teaching of critical inquiry, encouraging students in -active inquiry and critical thinking about the messages that we receive and create. The ability of students to explore issues thoughtfully —offers a way to speak out against injustice and unfairness (Pescatore, 2007). Critical thinking skills do not occur randomly or without 
effort; it takes structured, deliberate, and repetitive exposure and practice for students to develop insightful thinking. Furthermore, the University of Leeds (n/d) outlines the key steps in thinking critically, these include:

1. Describing - by clearly defining what you are talking about, what specifically was involved, where it took place and under what circumstances.

2. Reflecting - reconsidering a topic by taking into account new information or a new experience, or considering other viewpoints.

3. Analyzing - examining and then explaining how something is, including comparing and contrasting different elements and understanding relationships to your subject/topic.

4. Critiquing - identifying and examining weaknesses in arguments, as well as acknowledging its strengths. It's important to think of critiquing as 'neutral' and not negative.

5. Reasoning - using methods such as cause and effect to demonstrate logical thinking, as well as presenting evidence that either refutes or proves an argument.

6. Evaluating - can include commenting on the degrees of success and failure of something, or the value of something

The ability to analyze and creatively adapt to new situations is at the heart of critical thinking. Paul and Elder (2008, 2014b) asserted that critical thinking provides a vehicle for educating the mind. John Dewey would agree, as from his early work, we have increased our sense of the pragmatic basis of human thought (its instrumental nature), and especially its grounding in actual human purposes, goals, and objectives. Dewey (1910) also discussed critical thinking in terms of reflective thinking, which is an uneasiness in accepting the status quo and that critical thinking is both an emotional and intellectual component. Students must, therefore, be taught to examine, poke, question, and reflect on what they have learned. Scepticism, questioning, and reflection is essential. Dewey also stated that schools should have an intimate relationship with the community it serves.

From the review of the research concerning critical thinking and what components are considered important in high school education and later a life-long learning skill, the authors developed a 5-step, critical thinking teaching process as outlined in Table 2. Input from the study's nine experts who reviewed the model and from suggestions from other model developers, led to the selection of easy to remember letters that describe each step's process.

Table 2

The PUCSC Model's Five Steps to Teaching Critical Thinking

\begin{tabular}{|c|c|c|}
\hline Model Letter & Description & Supporting Theory/Discussion \\
\hline $\mathrm{P}-$ Step 1 & $\begin{array}{l}\text { Preparation for learning } \\
\text { management }\end{array}$ & $\begin{array}{c}\text { (Gulicheva, Lisin, Osipova, \& Khabdullin 2017; Paul et al., 1997; } \\
\text { Thaiposri \& Wannapiroon, 2015; Wichadee, 2014; Schroeder, } \\
\text { Minocha, \& Schneider, 2010). }\end{array}$ \\
\hline $\mathrm{U}-$ Step 2 & $\begin{array}{l}\text { Understanding and } \\
\text { practice }\end{array}$ & $\begin{array}{c}\text { (Bruner, 1976; Dewey, 1910; Halpern, 1993; Hove, 2011; McPeck, } \\
\text { 1981; University of Leeds, n/d). }\end{array}$ \\
\hline $\mathrm{C}-$ Step 3 & Cooperative solutions & (Johnson \& Johnson, 1994; Vijayaratnam, 2009) \\
\hline S-Step 4 & Sharing new knowledge & $\begin{array}{l}\text { (Innis, 2015; Leesa-nguansuk, 2015; Mandernach, 2006; University } \\
\text { of Leeds, n/d). }\end{array}$ \\
\hline C-Step 5 & $\begin{array}{l}\text { Creation of new } \\
\text { knowledge }\end{array}$ & (Dewey, 1910; Heick, 2014; Innis, 2015, Sternberg, 1997). \\
\hline
\end{tabular}




\subsection{Research Objectives}

The main purposes of this research were:

1. To develop an instructional model (PUCSC model) to enhance critical thinking among high school students and to develop their abilities in learning critical thinking processes.

2. To evaluate the experimental group's critical thinking abilities and academic achievement, and compare it to the control/traditional teaching group.

3. To evaluate and analyze the experimental group's students' satisfaction concerning their use of the PUCSC Model as a learning management tool.

\section{METHODOLOGY}

\subsection{Sample and data collection}

The population for the study consisted of 500 Bangkok secondary high school Mathayom Suksa 5 students (Junior $-11^{\text {th }}$ grade) enrolled in the second-semester of the 2016 academic year at Bangkok's Protpittayapayat School (November 2016 through February 2017 - 16 weeks total). The sample was selected by use of cluster random sampling to select 69 students from the population's total of 12 classrooms (500 students) as the study's sample group. The students were subsequently divided into two sub-groups of 35 experimental students (17 boys and 18 girls) and 34 traditional learning students (16 boys and 18 girls). The students' evaluation period was for 16 weeks, 2 hours each week, for a total of 32 hours. There was both a pre-course test and post-course test administered to evaluate each student's critical thinking skills. Furthermore, each student was administered a 20-item questionnaire concerning their overall impressions of the class and its learning management model process.

\subsection{Sample and data collection}

A focus group of nine experts was convened in August 2016 prior to the implementation of the study to assist with the development of the exploratory learning model. The experts commented that the learning management model has an appropriate learning process, which was later for an exploratory examination of Thai high school student critical thinking ability. Prior to this, however, a 'try-out' of the preliminary PUCSC Model was undertaken with ten Mathayom Suksa 6 students (seniors-12 ${ }^{\text {th }}$ grade). From the results of the 16-week try-out conducted by the primary researcher, the findings were revised according to the student's suggestions and used for the fine tuning of the final PUCSC Model used with the Protpittayapayat School in the second semester of the academic year 2016.

Based on the experts' assessment, it was found that the conceptualized PUCSC learning management model's overall fit was at the highest level (mean $\bar{x}=4.84$ and standard deviation $\sigma=0.26$ ). Content validity was also evaluated by using item-objective congruence (IOC) value. An IOC value of 0.5 or more is considered satisfactory, while the IOC consistency index of the test model was deemed to be highly reliable with a score of 0.92 (Rovinelli \& Hambleton, 1977).

\subsection{Critical thinking test}

For the study, the Watson-Glaser Critical Thinking Appraisal (CTA) test was used (Vong \& Kaewurai, 2017). The test consisted of a 30-item test with 5 options and included inferences, recognition of assumptions, deductions, interpretation, and evaluation of arguments. The IOC from this phase was 1.00 and the overall confidence value was 0.81 . 


\subsection{Academic achievement test}

The Thai test of academic achievement in social studies (SO 32102) at the upper secondary level was also used for student evaluation purposes. The characteristics of the quiz are patterned after Bloom's new taxonomy in which nouns are changed to verbs, including remembering, understanding, applying, analyzing, evaluating, and creating (Anderson \& Krathwohl, 2001). Difficulty index ranged between 0.35-0.80, discriminative power ranged between $0.30-0.80$ and reliability was found to be 0.86 .

\subsection{Student satisfaction questionnaire}

A questionnaire was used to collect student satisfaction data by use of a 5-level agreement scale, having a total of 20 items. The reliability value of 0.90 was calculated by using Cronbach's alpha (Tavakol \& Dennick, 2011) to ensure whether there was internal consistency within the items.

\subsection{Data analysis}

The one-way Multivariate Analysis Of Variance (one-way MANOVA) was used to determine whether there were any differences between the control and experimental groups on more than one continuous dependent variable. Furthermore, ways of comparison of the critical thinking ability and learning achievement of the experimental group who used the conceptualized PUCSC model, and the control group, which used traditional methods, was accomplished by use of mean score. Student satisfaction of from both groups was undertaken by use of average statistics and standard deviation.

Descriptive statistics (mean and standard deviation) were used to evaluate the quality of the experimental model. Content analysis was used to synthesize the learning management models that enhanced critical thinking ability of Thai high school students. A 5-level agreement scale was used to interpret the responses by calculating mean and standard deviation. The interpretation criteria that was used was $0.00-1.49$ as least appropriate, 1.50-2.49 was somewhat appropriate, 2.50-3.49 was moderately appropriate, 3.50-4.49 was very suitable, and $4.50-5.00$ was interpreted as most appropriate.

\section{EMPIRICAL RESULTS}

\subsection{Respondents' characteristics}

The study tested the baseline variance agreement with Box's $\mathrm{M}$ test (Table 3), which is used to determine whether two or more covariance matrices are equal (Tabachnick \& Fidell, 2001). It was found that the variance of all the groups was not significantly different (.05). Additionally, the preliminary agreement of the correlation coefficient was tested, which was then followed by Bartlett's Test for homogeneity of variance which is derived from Box's test (Snedecor \& Cochran, 1989). Results indicated that the initial agreement of the relationship of the dependent variables, followed by Bartlett's test statistic, found that the average value relationship of critical thinking ability to achievement at the end of the course to be statistically significant (.05), and when compared to the control group, it was found that the experimental learning management model achieved higher results in both critical thinking (17.62) and postlearning achievement (19.26). 
Table 3

Average comparison of critical thinking ability and achievement after class classified by learning style

\begin{tabular}{|c|c|c|c|c|c|c|c|}
\hline $\begin{array}{l}\text { Dependent } \\
\text { Variable }\end{array}$ & $\begin{array}{l}\text { Independent Variable } \\
\text { (Learning Model/Style) }\end{array}$ & $\begin{array}{l}\text { Students } \\
\text { (n) }\end{array}$ & Mean & $\sigma$ & $\mathrm{F}$ & Sig. & Comparison \\
\hline $\begin{array}{l}\text { Critical } \\
\text { thinking } \\
\text { ability }\end{array}$ & $\begin{array}{l}\text { Experimental group } \\
\text { Control group }\end{array}$ & $\begin{array}{l}34 \\
34\end{array}$ & $\begin{array}{l}17.62 \\
14.21\end{array}$ & $\begin{array}{l}3.28 \\
2.87\end{array}$ & \multirow[t]{2}{*}{$20.80^{*}$} & \multirow[t]{2}{*}{.000} & $\begin{array}{c}\text { Experimental }> \\
\text { Control }\end{array}$ \\
\hline Achievement & $\begin{array}{l}\text { Experimental group } \\
\text { Control group }\end{array}$ & $\begin{array}{l}35 \\
35\end{array}$ & $\begin{array}{l}19.26 \\
18.83\end{array}$ & $\begin{array}{l}3.64 \\
3.24\end{array}$ & & & $\begin{array}{c}\text { Experimental }> \\
\text { Control }\end{array}$ \\
\hline
\end{tabular}

Box’s M Test: F $=.275$, Sig $=.844$; Bartlett's Test: $\mathrm{X}^{2}=25.387, *$ Sig $=.000$.

Results from the tests showed that the average value of critical thinking ability to the average achievement after the testing ended, showed the relationship was statistically significant (.05). As a result, the researchers compared the results of Table 4 and determined that after the posttest, data showed the average of critical thinking ability and post-learning achievement were higher than before the study.

Table 4

Comparison of critical thinking ability and achievement classified by test category

\begin{tabular}{|c|c|c|c|c|c|c|c|}
\hline Dependent Variable & $\begin{array}{c}\text { Independent } \\
\text { Variable }\end{array}$ & $\begin{array}{c}\text { Students } \\
\text { (n) }\end{array}$ & Mean & $\sigma$ & $\mathrm{F}$ & Sig & Comparison \\
\hline $\begin{array}{c}\text { Critical thinking } \\
\text { ability }\end{array}$ & $\begin{array}{l}\text { Pre-test } \\
\text { Post-test }\end{array}$ & $\begin{array}{l}34 \\
34\end{array}$ & $\begin{array}{l}17.62 \\
14.38\end{array}$ & $\begin{array}{l}3.28 \\
2.73\end{array}$ & \multirow{2}{*}{$20.51 *$} & \multirow{2}{*}{.000} & $\begin{array}{c}\text { Experimental } \\
>\text { Control }\end{array}$ \\
\hline Achievement & $\begin{array}{l}\text { Pre-test } \\
\text { Post-test }\end{array}$ & $\begin{array}{l}\mathbf{3 5} \\
\mathbf{3} 5\end{array}$ & $\begin{array}{l}19.26 \\
12.83\end{array}$ & $\begin{array}{l}3.64 \\
\mathbf{2 . 6 2}\end{array}$ & & & $\begin{array}{c}\text { Experimental } \\
>\text { Control }\end{array}$ \\
\hline
\end{tabular}

Box's M Test: $\mathrm{F}=2.399, \mathrm{Sig}=.066$; Bartlett's Test: $\mathrm{X}^{2}=23.358, * \operatorname{Sig}=.000$.

The experimental group student results concerning the satisfaction analysis on the PUCSC learning management model are shown in Table 5 , which indicate a very high overall rate.

Table 5

Experimental Student Group Satisfaction of the PUCSC Learning Management Model

\begin{tabular}{|c|c|c|c|c|}
\hline Side & mean & $\boldsymbol{\sigma}$ & Satisfaction level & Rank \\
\hline Content & 4.56 & 0.12 & most appropriate & 1 \\
\hline Learning management activities & 4.47 & 0.07 & very suitable & 3 \\
\hline Learning management media & 4.50 & 0.18 & most appropriate & 2 \\
\hline Benefits and satisfaction & 4.47 & 0.07 & very suitable & 3 \\
\hline Measurement and evaluation & 4.47 & 0.07 & very suitable & 3 \\
\hline Average & 4.49 & 0.10 & very suitable & \\
\hline
\end{tabular}




\section{DISCUSSION}

"Habits of mind" such as "analysis, interpretation, precision and accuracy, problem-solving, and reasoning" can be as, or more important than, content knowledge in determining success in university courses (Conley, 2008). Furthermore, todays 21st Century citizens must be active critical thinkers if they are to compare evidence, evaluate competing claims, and make sensible decisions (National Education Association, 2011). Therefore, the researchers developed and evaluated the PUCSC Model to help educators develop and enhance Thai high school student critical thinking skills. The model's validity and strength were confirmed in large part by the following discussion.

Results showed that critical thinking ability and learning achievement within the experimental group had a higher critical thinking ability than the control group, at the .01 level.

Step 1, which consisted of preparation for learning management $(\mathrm{P})$, is validated by research from Thaiposri and Wannapiroon (2015), which indicated that in use of social media and ICT in teaching critical thinking skills, preparation was highly important, with teaching staff forming the core of an innovative educational environment (Gulicheva et al., 2017).

Learning management systems (LMS) are also recognized now as powerful tools in the preparation of critical thinking skills education (Wichadee, 2014), with LMS platforms such as Moodle becoming widely popular in tertiary education (Schroeder et al., 2010).

Step 2 consisted of understanding and practice (U). This is confirmed by Halpern (1993), which stated that critical thinking improvement can be obtained with appropriate instruction. McPeck (1981) also found that critical thinking can be taught through drills, exercises, and problem-solving. Bruner (1976) also stated that the outcome of cognitive development is thinking, and the purpose of education is to facilitate problemsolving skills.

Step 3 consisted of cooperative solutions (C). In support of this, Vijayaratnam (2009) concluded that adopting critical thinking tasks centred on cooperative learning strategies helps improve social relationships among team members. Johnson and Johnson (1994) confirmed this also, as students who have opportunities to work collaboratively on real-world tasks, learn faster and more efficiently, and have greater retention and feel more positive.

Step 4 revolves around the idea of sharing new knowledge (S), which in a 21st Century classroom is easier to due to technology. LMS environments such as Moodle, are powerful tools in classroom learning management (Leesa-nguansuk, 2015), as well as in the development of student critical thinking (Mandernach, 2006).

Step 5 is the creation of new knowledge (C). Sternberg (1997) indicated that this means teachers should encourage students to apply, use, and put into practice, implement, employ, and render practical what they know. Heick (2014), also stated that the essential attribute of intelligent human beings is not only having information but also knowing how to act on it.

Part 2 consisted of the comparison of the mean scores concerning critical thinking abilities and academic achievement. From the results, it was found that the experimental group who used the PUCSC model to enhance the critical thinking ability had a better ability to think critically, and the learning achievement after class was higher than before.

This is consistent with Vong and Kaewurai (2017), which evaluated the critical thinking process of teacher trainees in Cambodia, and determined that triggering activity, identifying problems, investigating related data, discussing findings, evaluating findings, creating solutions, presenting solutions, and reflecting on the learning outcome were key.

Part 3 entailed the analysis of the experimental group's student satisfaction concerning their use of the PUCSC Model as a learning management tool. The results showed that the students' satisfaction with the 
experimental model was considered at a high level $(\bar{x}=4.49)$. When considering each aspect of the content, the researcher/instructor-prepared materials and media was found to have the highest level of satisfaction on learning activities.

$\mathrm{Ng}$ (2001) argued that in Asia, creative and critical thinking is culturally limited as Asians place a great emphasis on obedience and conforming to group expectations, together with the avoidance of losing face as a result of appearing different. Praparpun (2012), however, in a discussion about Thailand's path to 21st century social, political, and economic development, felt that Thai youth must learn skills in critical thinking, collaborative problem solving, and the effective use of internet technologies, both in communication and in searching for vital information. Alazzi (2008) agreed with the recognition of critical thinking in the junior high school environment, and inferred that more exploration on how critical thinking is taught, learned, and judged is required to explicate. This has been confirmed as the current critical shortage of industry-ready skilled workers presents one of the biggest challenges for the five core member countries of the Association of Southeast Asian Nations, ASEAN-5, as they strive to realize their economic visions (Kraisuth \& Panjakajornsak, 2017). Thailand therefore, must not rely on a legacy of rote learning, which blocks the process for critical change.

\section{CONCLUSION}

The author developed PUCSC critical thinking learning/teaching model was determined to be an effective tool in the teacher's educational toolkit. As current literature suggests, all students at all academic levels will clearly benefit from curricula steeped in critical thinking strategies and practice. Students who master the ability to think critically and insightfully will perform better academically in their current high school setting, and will also be better prepared for the rigors and enhanced academic expectations in college. Faced with an aging population, Thailand needs to find more effective ways to prepare today's youth to meet the demands of a digitally enabled, knowledge worker with critical thinking skills demanded by global industry. Thai students need to be able to creatively think and problem solve. Solving any problem creatively, offering unique insights for potential solutions, demands the ability to be able to think critically; it also requires that students have confidence in their ability to do so. Teachers and administrators must take responsibility for this process, as students need frequent and repeated exposure to critical thinking practices, whose training must begin at an early age.

\section{REFERENCES}

Alazzi, K. (2008). Teachers' perceptions of critical thinking: A study of Jordanian secondary school social studies teachers. The Social Studies, 99(6), 243-248. doi: 10.3200/tsss.99.6.243-248

Anderson, L., \& Krathwohl, D. A. (2001). Taxonomy for Learning, Teaching and Assessing: A Revision of Bloom's Taxonomy of Educational Objectives. New York, NY: Longman.

Barrington, L., Casner-Lotto, J., \& Wright, M. (2006). Are they really ready to work? Employers' perspectives on the basic knowledge and applied skills of new entrants to the 21 st Century U.S. workforce. The Partnership for 21 st Century Skills. Retrieved from http://tinyurl.com/j2c5uh6.

Bassham, G., Irwin, W., Nardone, H., \& Wallace, J. M. (2013). Critical thinking: A student's introduction (5th ed.). New York, NY: McGraw-Hill.

Boa, E. A., Wattanatorn, A., \& Tagong, K. (2018). The development and validation of the Blended Socratic Method of Teaching (BSMT): An instructional model to enhance critical thinking skills of undergraduate business students. Kasetsart Journal of Social Sciences, Advance online publication. doi: 10.1016/j.kjss.2018.01.001

Bruner, J. S. (1976). The process of education. Cambridge, MA: Harvard University Press.

Chaiyasut, C., Samuttai, R., Phuwiphadawa, S., \& Inthanet, N. (2014). Factors and indicators of teachers' roles that promote lifelong learning skills of students at the basic education level. International Journal of Behavioral Science, 9(2), $71-86$. 
Conley, D. T. (2008, February 8). Toward a more comprehensive conception of college readiness. Educational Policy Improvement Center. Retrieved from http://tinyurl.com/mg69mv5.

Costa, A. \& Kallick. B. (2014). Dispositions: Reframing teaching and learning. Thousand Oaks, CA: Corwin Press.

Dewey, J. (1910). How we think. Boston, MA: D. C. Heath \& Co. Retrieved from http://tinyurl.com/16q46mq

European Union. (2015). 2015 joint report of the council and commission on the implementation of the strategic framework. for European cooperation in education and training (ET 2020). Retrieved from http://tinyurl.com/zctcbre

Galinsky, E. (2010). Mind in the making: The seven essential life skills every child needs. New York, NY: Harper Collins Publishing.

Geertsen, H. R. (2003). Rethinking Thinking about Higher-Level Thinking. Teaching Sociology, 31(1), 1-19. Retrieved from http://tinyurl.com/nyhb6qr.

Gulicheva, E., Lisin, E., Osipova, M., \& Khabdullin, A. (2017). Leading factors in the formation of innovative education environment. Journal of International Studies, 10(2), 129-137. doi: 10.14254/2071-8330.2017/10-2/9

Gupta, G. (2005). Improving students' critical thinking, logic, and problem-solving skills Journal of College Science Teaching, 34(4), 48-51.

Hager, P., \& Kaye, M. (2006). Critical thinking ability and teacher effectiveness. Higher Education Research \& Development, 10(2), 177-186. doi: 10.1080/0729436910100205

Halpern, D. F. (1993). Assessing the effectiveness of critical thinking instruction. The Journal of General Education, 42(4), $238-254$.

Hayes, K., \& Devitt, A. (2008). Classroom discussions with student-led feedback: a useful activity to enhance development of critical thinking skills. Journal of Food Science Education, 7(4), 65-68. doi: 10.1111/j.15414329.2008.00054.x

Heick, T. (2014. February 27). Are you teaching content or teaching thought? Retrieved from http://tinyurl.com/ktacc5n

Hove, G. (2011). Developing critical thinking skills in the high school English classroom. (Unpublished master's thesis). University of Wisconsin-Stout, WI. Retrieved from https://tinyurl.com/y $7 \mathrm{dm} 8 \mathrm{blh}$

Innis, G. (2015). Critical thinking: Another essential life skill. Help children learn to think critically to achieve success in school and in life. Retrieved from https://tinyurl.com/ya337bt4

Johnson, D., \& Johnson, R. (1994). Leading the cooperative school. Edina, MN: Interactions Book Co.

Jones, C., \& Pimdee, P. (2017). Innovative ideas: Thailand 4.0 and the fourth industrial revolution. Asian International Journal of Social Sciences, 17(1), 4 - 35. doi: 10.29139/aijss.20170101

Kraisuth, D., \& Panjakajornsak, V. (2017). Thai engineer ASEAN readiness: A structural equation model analysis. Asia-Pacific Social Science Review, 16(3), 96-117. Retrieved from http://tinyurl.com/m2spsas

Leesa-nguansuk, S. (2015, November 23). Chiang Mai University is at the forefront of educational institutions in adopting digital technology in the classroom. Bangkok. Post. Retrieved from http://tinyurl.com/lkfcovk

Mandernach, B. J. (2006). Thinking critically about critical thinking: Integrating online tools to promote critical thinking. Insight: A collection of faculty scholarship, 1, $41-50$.

McPeck, J. E. (1981). Critical thinking and education. New York, NY: St. Martin's Press.

Mendelman, L. (2007). Critical thinking and reading. Journal of Adolescent and Adult Literacy, 51 (4), 300- 304.

National Association of Colleges and Employers. (2016, Sep. 28). Class of 2016 believes it is "Career Ready," but is it? Retrieved from http://tinyurl.com/ya8a559g

National Association for Media Literacy Education. (2010). The core principles of media literacy education. Retrieved from https://tinyurl.com/ydyavdcj

National Council for Excellence in Critical Thinking (2017). A draft statement of principles Retrieved from https://tinyurl.com/y79xcx52

National Education Association. (2011). Preparing 21st-century students for a global society. Retrieved from http://tinyurl.com/mttg8wz

$\mathrm{Ng}$, A. K. (2001). Why Asians are less creative than Westerners. Singapore: Prentice-Hall.

OECD/UNESCO. (2016). Education in Thailand: An OECD-UNESCO perspective. Reviews of national policies for education, Paris, France: OECD Publishing. Retrieved from http://tinyurl.com/ml6nufq

Ornstein, A. C., \& Levine, D. U. (2006). Foundations of Education (8th ed.). Boston, MA: Houghton Mifflin.

Ornstein, A. C., Pajak, E. F., \& Ornstein S. B. (2011). Contemporary issues in curriculum (15th ed.), Boston, MA: Pearson Education.

Paul, R., \& Elder, L. (2008). Critical thinking: The nuts and bolts of education. Optometric Education, 33(3), 88-91. Retrieved from http://www.opted.org/i4a/pages/index.cfm

Paul, R., \& Elder, L. (2014a). The Miniature Guide to Critical Thinking: Concepts and Tools. Tomales, CA: Foundation for Critical Thinking. Retrieved from https://tinyurl.com/y7p5xz84

Paul, R., \& Elder, L. (2014b). Critical thinking: Tools for taking charge of your professional and personal life. Upper Saddle River, NJ: Pearson Education. 
Paul, R., Elder, L., \& Bartell, T. (1997). California teacher preparation for instruction in critical thinking: Research findings and policy recommendations: State of California, California, Commission on teacher credentialing, Sacramento, CA.

Pescatore, C. (2007). Current events as empowering literacy: For English and social studies teachers. Journal of Adolescent \& Adult Literacy, 51(4), 326-339. doi: 10.1598/jaal.51.4.4

Praparpun, Y. (2012). Developing Ramkhamhaeng University history of economic development of

Southeast Asia (EC 3902) students’ critical thinking skills. Retrieved from

http://tinyurl.com/ybvxcp7p.

Reeve, E. M. (2016). 21st-century skills needed by students in technical and vocational education and training (TVET). Asian International Journal of Social Sciences, 16(4), 65 - 82. doi: 10.29139/aijss.20160404

Rovinelli, R. J., \& Hambleton, R. K. (1977). On the use of content specialists in the assessment of criterion-referenced test item validity. Dutch Journal of Educational Research, 2, 49-60.

Rujivanarom, P. (2016, December 14). School system's failure to teach logical thinking linked to low PISA scores. The Nation. Retrieved from http://tinyurl.com/168ugux.

Schroeder, A., Minocha, S., \& Schneider, C. (2010). The strengths, weaknesses, opportunities and threats

of using social software in higher and further education teaching and learning. Journal of Computer

Assisted Learning, 26(3), 159-174.

Siemens, G. (2005). Connectivism: A learning theory for the digital age. International Journal of Instructional Technology and Distance Learning, 2(1), 3-10. Retrieved from http://tinyurl.com/kqq4bz6

Snedecor, G. W., \& Cochran, W. G. (1989). Statistical Methods. Ames, IA: Iowa State University Press.

Sternberg, R. J. (1997). A triarchic view of giftedness: Theory and practice. In N. Coleangelo \& G. A. Davis (Eds.), Handbook of Gifted Education (pp. 43-53). Boston, MA: Allyn and Bacon.

Sulaiman, W. S. W., Rahman, W. R. A., \& Dzulkifli, M. A. (2008). The relationship between critical thinking dispositions, perceptions towards teachers, learning approaches and critical thinking skills among university students. The Journal of Behavioral Science, 3(1), 122 - 133. Retrieved from http://tinyurl.com/kdeqylg

Tabachnick, B. G., \& Fidell, L. S. (2001). Using Multivariate Statistics. Boston, MA: Allyn and Bacon.

Tavakol, M., \& Dennick, R. (2011). Making sense of Cronbach's alpha. International Journal of Medical

Education, 2, 53-55. doi: 10.5116/ijme.4dfb.8dfd

Taylor, J. (2012, August 14). Philosophical teaching will get students thinking for themselves again. The Guardian. Retrieved from https://tinyurl.com/ybsn4de6

Thaipusam, P., \& Wannapiroon, P. (2015). Enhancing students' critical thinking skills through teaching and learning by inquiry-based learning activities using social network and cloud

computing. Procedia - Social and Behavioral Sciences, 174, 2137 - 2144. Retrieved from http://tinyurl.com/med4g9y

Thayer-Bacon, B. J. (1998). Transforming and redescribing critical thinking: Constructive thinking. Studies in Philosophy and Education 17(2). doi: 10.1023/A:1005166416808

University of Leeds ( $\mathrm{n} / \mathrm{d}$ ). Understanding critical thinking. Retrieved from https://tinyurl.com/y7xqvgf4

UNODC. (n/d). Module 7 - Life skills. Retrieved from https://tinyurl.com/y6vzv5nh

Vijayaratnam, P. (2009). Cooperative learning as a means to developing students' critical and creative thinking skills. Proceedings of the $2^{\text {nd }}$ International Conference of Teaching and Learning. Retrieved from http://tinyurl.com/mtjkwky.

von Glasersfeld, E. (1990). An exposition of constructivism: Why some like it radical. Journal for Research in Mathematics Education - Monograph. 4, 19-29 \& 195-210. doi: $10.2307 / 749910$

Vong, S. A., \& Kaewurai, W. (2017). Instructional model development to enhance critical thinking and critical thinking teaching ability of trainee students at regional teaching training centre in Takeo Province, Cambodia. Kasetsart Journal of Social Sciences, 38, 88 - 95. doi: 10.1016/j.kjss.2016.05.002

Vygotsky, L. S. (1930). Mind and Society. Cambridge, MA: Harvard University Press.

Vygotsky, L. S. (1978). Mind in Society: The Development of Higher Psychological Processes. M. Cole, V. John- Steiner, S. Scribner, \& E. Souberman, E. (Eds.), Cambridge, MA: Harvard University Press.

Wichadee, S. (2014). Students' learning behaviour, motivation and critical thinking in learning management systems. Journal of Educators Online, 11(3): 1 - 21. doi: 10.9743/jeo.2014.3.3

Wood, D. J., Bruner, J. S., \& Ross, G. (1976). The role of tutoring in problem-solving. Journal of Child Psychiatry and Psychology, 17(2), 89-100. doi: 10.1111/j.1469-7610.1976.tb00381.x

World Health Organization (1999). Partners in life skills education. Retrieved from http://www.who.int/mental_health/media/en/30.pdf 